\title{
Main Challenges Encountered by Students in Learning English as a Foreign Language
}

\author{
Issa Safaa Issa Al-Khalidi \\ English Department, College of Basic Education \\ Maysan University
}

DOI: $10.37648 /$ ijrssh.v10i04.004

Received:18 ${ }^{\text {th }}$ August, 2020; Accepted:04th September, 2020; Published:22nd September,2020

\begin{abstract}
Learning English is quite challenging in non-English native countries.The problems encountered during the learning process make it difficult. For some country where English use is taboo, you have to be persistentto learn it efficiently. This paperexplores the main challenges of the students that hinder them from learning English languageeffectively. Furthermore, we will explore student's exposure to English language which can advance our understanding of their application outside learning institutions. In this study, the target sample is the first stage college students taking basic education. In order to generate relevant data, the researcher administered a systematic questionnaire to the randomly chosen students.A qualified evaluator then rated the students' communication skills with the aid of a recorder and an evaluation sheet. Significantly, the majority of the students reported that fear and anxiety is the most challenging factor they face while learning English language. In spite of the challenges, the evaluator gave "very good" and "good" remarks to the majority of them. Interestingly, this could be attributed by the students' constant application of their learning at home as reported. While this paper had answered the main objective of the study, more researches are suggested to gain a complete grasp on the students' perspectives towards English learning.
\end{abstract}

\section{INTRODUCTION}

The demand for learning English has been drastically increasing as most of the non-English countries learn to embrace western initiated developments. In order to improve communication and unity hindered by language barrier, teaching the international language became arequirement in all schools worldwide. While this has indeed brought improvement in communication to the international arena, many students face challenges in learning the language and eventually results in poor communication within the academia. In fact, in some countries, especially in second and third world countries, fluency in English languageis used as measurement of intelligence, leaving the challenged student a target of laughing-stock and bullying. This social marginalization becomes a heavy burden and can eventually affect the motivation of the students to learn. This factor adds up the burden of learning English which apparently pollutes the overall learning experience of the student.

On the other hand, the development of English communication has opened doors to a wide range of opportunities to non-western countries. One most popular example of this is the outsourcing scheme employed by many American businesses to suffice the demand of their customers. It generated 
(IJRSSH) 2020, Vol. No. 10, Issue No. IV, Oct-Dec

millions of jobs which help boost the national economy, not to mention the continuously increasing demand for tutors too for teaching English as secondary language online. In this sense, we can realize the importance of the English language not just on the individual lives but also for the progress of the country. This is the reason why the government of every country sees to it that it has done its responsibility by providing quality education to its citizens, and if possible continuously revises its scheme to ensure its efficiency.

\section{PROBLEM STATEMENT:}

Learning English as secondary language may seem easy for some but for many students, it is an uphill experience. The pressure a student may experience out from demands for fast progress may in different ways impede the learning process. The problem may arise not from a single aspect but may have been an accumulated effect from various factors. In addition to these factors is the dynamic nature of English. The language is continuously evolving and other people, who are stuck in learning the basics, may find it hard to catch up. Instructors and teachers should dig deeper to find out of what the real problem is behind the slow learning progress of the students instead of seeing just the tip of the iceberg. They should realize the critical role they play in developing the student's skills as it is the very fundamental pillars of a country's genuine success.

\section{OBJECTIVE:}

Learning English as a foreign language may seem easy for some but for many students, it is an uphill experience. The pressure a student may experience out from demands for fast progress may in a different way impede the learning process. The problem may arise not from a single aspect but may have been an accumulated effect from various factors. In addition to these factors is the dynamic nature of English. The language is continuously evolving and other people who find themselves stuck in learning the basics may find it hard to catch up. Instructors and teachers should dig
e-ISSN: 2249-4642, p-ISSN: 2454-4671

deeper to grasp what the real problem is behind the slow learning progress of the students instead of seeing just the tip of the iceberg. They should realize the critical role they play in developing the student's skills as it is the very fundamental pillars of a country's genuine success.

\section{LIMITATIONS OF THE STUDY:}

Although the study limits to the participants' stage level (as this study only focuses on the students in the first stage in college), it is important to note that this population is unique making it an ideal subject of researches. Transition in this level can be so overwhelming that it can make or break the student's future in college. As Kannan (Kannan, 2009. p.2) described, it is at this stage that the student can feel "freedom" from the rigorous training they had undergone from the past levels of education. Due to the notion that college is liberal in teaching the students, motivation and discipline may start to bleak. Thus, it is of utmost importance to correct, monitor and counsel the students at this stage of their development. Another limitation of the study is its time-bound nature making it unique from the past studies. Meaning, this is relevant to the current and existing environmental condition and whenever the demands and pressure changes in the future (as it always does), this study will still provide a firm foundation in the development of new results and discoveries.

\section{REVIEW OF SOME RELATED LITERATURE}

Many studies and researches investigating English language learning flood the literature. This fact alone emphasizes how important and disturbing the stunted growth of English learning is in many countries worldwide. Applying the learning in daily practice, both inside and outside the school is the usual method to improve English skills as recommended by many studies. This, however, is challenging as bilingual nature always kicks in especially if you are submerged in an environment where the English language is just secondary and rarely a used language. What makes 
(IJRSSH) 2020, Vol. No. 10, Issue No. IV, Oct-Dec

English different from other subjects is that it needs a constant application to achieve mastery and fluency. Also, one commonly observed mistake in most education systems is that teachers usually focus on preparing the students for examinations and sometimes tend to forget their true purpose which is to develop their students' English skills. Studying it for the mere purpose of passing examinations makes the learning process ineffective and futile. While the prior mentioned gaps takes a seat on the several main failures causing lack of progress, Schwartz and Terrill (Schwartz and Terril, 2000:Wold, 2006, p.12) also mentioned few factors affecting English language learning. These include the following:

- Limited skills in native language brought about by limited previous education;

- Ineffective study habits;

- Lack of familiarization on the Roman alphabet, especially if the native language is way too different and is in the non-Roman alphabet;

- Unmet expectations between the instructors and learners with regards to the teaching styles;

- Socio-cultural factors such as age, physical health, social identity

- Issues with work, health, and family;

- Sporadic attendance during classes.

These findings clearly indicate that there are deeper reasons behind a learner who makes little or no progress at all. Hybrid or a combination of these factors can definitely lead to learning failure. It is notable that in the listed reasons, everything makes logical connection except on the first reason. Then how can one relate difficulty in using the native language to difficulty in learning the foreign language? The reason behind it lies in the pivotal role the first language plays in learning the second language, which is, in this case, the English language. As Ganschow (Ganschow et.al,1998: Wold, 2006, p.15) had described it, native language provides a foundation in learning a foreign language. That is an underdeveloped native language experience can
e-ISSN: 2249-4642, p-ISSN: 2454-4671

be coupled and equated with an incomplete acquisition of necessary skills required for effective language learning.

It is also important to note that not all issues are rooted in the student. Sometimes, it also comes from the instructor himself. Several researchers find it disturbing when the teaching styles being provided by the teachers are not in the correct way as it should be. Being too nice can lessen the teaching efficiency as it reduces the strength needed to get full attention and participation (Wold, 2006, p.41). On the other hand, imposing too much discipline in teaching, not to mention the harsh apprehension styles being implemented by the teachers to correct the students' behavior, is not advisable. Although from the teacher's point of view, it is too stressful handling a class mixed with competent and slow English learners, the teacher should understand that their responsibility is not limited to above average students alone (Kannan, 2009, p.3). It is their primary task to guide and teach struggling students too and punishing them causing psychological consequences is already an unjustifiable attempt of crossing the line. The psychological stress it causes to the students will eventually give way to distorted self-esteem, selfconfidence and also affects their risk-taking abilities (Crookall and Oxford,1991: Wold, 2006, p.67).

Many countries exert maximum efforts to solve this dilemma in the world of English linguistics. Muhammad (Muhammad et.al, 2018, p.12), in his study on the Nigerian community, suggested that learning authorities should enforce great effort in promoting English in speaking, listening, reading and writing in classrooms. To improve motivation and gain sufficient attention, the teachers should upgrade their teaching methods to a more interesting and interactive way. These could include using audio and visual aids in teaching. Most importantly, he advised that teachers should improve their knowledge skills too so they can teach English skills more effectively. This is effective at some degree, however, it should be highlighted that learning does not only happen at the four corners of the classroom. 
(IJRSSH) 2020, Vol. No. 10, Issue No. IV, Oct-Dec

Taking into account that a student spends only a part of his time learning the English language inside the school, their usual outlet should be considered too. Akbari (Akbari, 2015, p. 395) highlights the importance of improving the existing English teaching system. She pointed out that prolonging the current system costs not only efforts to both sides (for student and teacher) but also the national government's pocket. For instance, in cases like Iran where English teaching starts at the age of 11, to first grade in junior high school up to the university level, English communication is still a big issue. If summed up, the English learning will eventually reach almost 7 years in Iran and it is pretty disturbing to know that the government's investment to improve education had gone to peril.

\section{METHODOLOGY}

The increasing number of studies investigating English as a Second and foreign Language (EFL) is overwhelming. The research design adapted Riyaz's (Riyaz and Mullick, 2016) methodology. From the first-year college student taking Basic Education, a representative sample was taken for data generation. The sample included randomly chosen twenty (20), students. An equal number of respondents from female and male students was chosen to participate. They were expected to represent the whole population and the conclusion was drawn out from them.

\section{DATA GATHERING AND ANALYSIS}

The gathered information were classified into four connected sections. These are:
e-ISSN: 2249-4642, p-ISSN: 2454-4671

Assessment of English Language Exposure Identifying Main Challenges in Learning the English Language

Evaluation on Students Perception of the English Language

Assessment on English Communication Skills through Direct Observation

The study used the existing researches and studies to determine the common problems and challenges in learning the English language (Khan, 2011; Muhammad et.al, 2018; Wold, 2006; Khajloo, 2013). With the informant's permission, the researcher recorded the interview. After the interview, a qualified evaluator examined the communication skills of the students. The evaluator then rated the communication skill of each student using the "English Communication Evaluation Sheet".

\section{RESULTS AND DISCUSSION}

The students reported that they often expose themselves to English through listening to English songs $(30 \%)$ and using the language in talking with their family members $(30 \%)$. These results could indicate positive inputs for English language skills development among the students. Moreover, the English language is effectively learned with simultaneous application extending outside the four walls of the classroom. Home is where a student spends most of his time and using English more often in the communication will give them the opportunity to practice their learning from schools. By contrast, in the study conducted among the students in India, most students (46.2\%) never use English at home with their family members (Riyaz, 2016, p. 64), providing them less opportunity to language exposure.

Table 1: Activities Associated with English Language Exposure

\begin{tabular}{llll}
\hline Activities & $\begin{array}{l}\text { Often } \\
(\%)\end{array}$ & $\begin{array}{l}\text { Sometimes } \\
(\%)\end{array}$ & $\begin{array}{l}\text { Rarely } \\
(\%)\end{array}$ \\
\hline Watching English movies & 0.2 & 0.5 & 0.3 \\
Reading English books & 0.25 & 0.5 & 0.25 \\
Reading English newspaper/magazine & 0.2 & 0.4 & 0.4 \\
\hline
\end{tabular}




\begin{tabular}{llll}
\hline Reading English articles online & 0.25 & 0.35 & 0.4 \\
Listening to English songs & 0.3 & 0.5 & 0.2 \\
\hline Speaking English inside the classroom & 0.25 & 0.5 & 0.25 \\
Speaking English with family members & 0.3 & 0.5 & 0.2 \\
$\begin{array}{l}\text { Speaking English with friends } \\
\text { Speaking English with other people (i.e. neighbors, } \\
\text { strangers etc.) }\end{array}$ & 0.25 & 0.35 & 0.4 \\
\hline
\end{tabular}

To understand the students' perspectives in learning the English language, they were given a chance to rate the learning difficulty level. The chart below shows the result on their quick assessment of English language learning. Notably, the majority (40\%) of them reported that they find it hard to learn it. On the other hand, only $25 \%$ of the students find English learning as an easy task.

Figure1: Chart showing English learning difficulty level

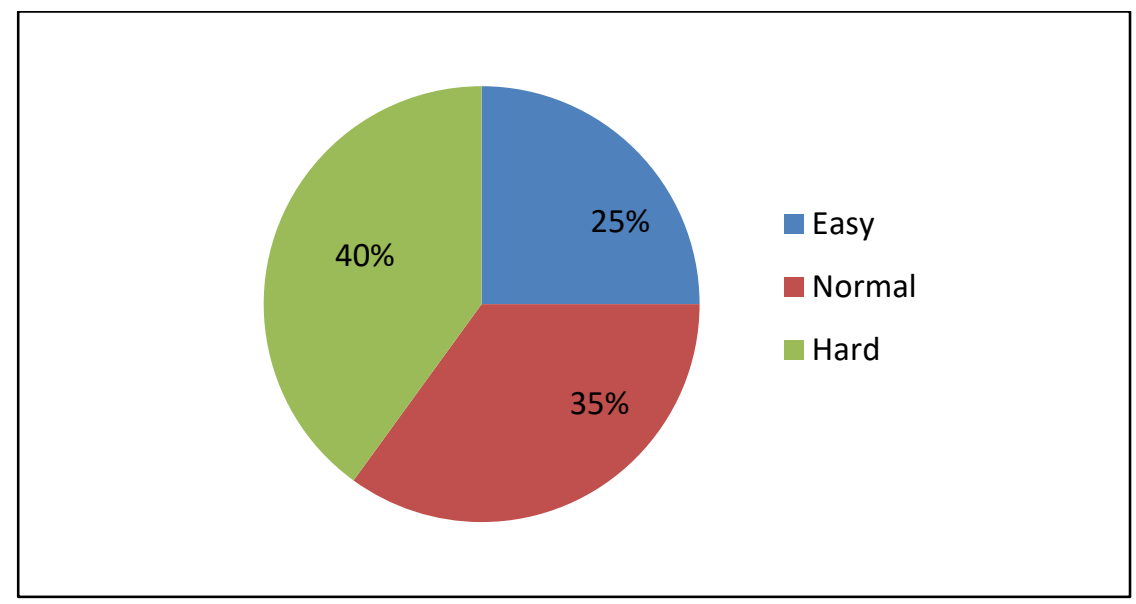

Although this study is limited to one quick assessment question only, there are existing researches which investigate specific reasons behind the difficulty of learning English language per se. Ungureanu (Ungureanu, 2015, p. 84-85) cited few reasons why English learning is difficult for some people. Her first reason highlights the vastness of rules in English grammar. She expressed the ambiguity of English grammar rules in humorous lines. The following is an excerpt taken from Ungureanu's study:

"We'll begin with a box, and the plural is boxes,

But the plural of ox becomes oxen, not oxes.

One fowl is a goose, but two are called geese,

Yet the plural of moose should never be meese.

You may find a lone mouse or a nest full of mice,

Yet the plural of house is houses, not hice..."

Another reason she cited is the existence of some keywords that have different meanings that can be used as different part of speech in different contexts. She provided the following examples: 
Table 2: Example of words with multiple meanings

\begin{tabular}{|c|c|}
\hline Word & Meaning/Use \\
\hline Table & $\begin{array}{l}\text { Lunch table (Social language) } \\
\text { Periodic table of elements (Science) } \\
\text { Table of contents (ELA) } \\
\text { Multiplication table (Math) } \\
\text { To table (delay) the discussion (Social Studies }\end{array}$ \\
\hline Plot & $\begin{array}{l}\text { Plot of a story (ELA) } \\
\text { Plot of land (Geography) } \\
\text { Plot ordered pairs on a graph }\end{array}$ \\
\hline
\end{tabular}

Furthermore, the students identified the main challenges they usually face. "Anxiety and fear in using the English language" is the most common challenging factor (25\%) for students. This result is consistent with the result of the various studies in countries where English is not the primary language. In the Philippines, the "Fear of negative evaluation and the general feeling of anxiety" is the primary challenge faced by the first year college students as far as the English language learning is concerned. Two of the main reasons of it are: (1) the anxiety experienced when having conversation with classmates or with teachers using English language (Mamhot et al, 2013, p. 214) and (2) fear of negative evaluation. However, upon further study, it was found out that students were neutral with their feelings regarding communication comprehension. That is, they are neither acknowledging that they fear nor they deny that they feel fear (p. 219). Neutrality was also observed between the display of anxiety and confidence among them. The researcher hypothesized that it could be attributed to the factor that: (1) these students have been exposed to the English language since they are children or (2) they might feel that it is too bold for their age and level (first-year college students) to showoff their confidence. Either way, the researcher did not associate the absence of real competency in English language use as the main reason of generating fear and anxiety among the students. Instead, the researcher denoted that the problem lies in the common notion that they might commit mistakes and end up being embarrassed; the same main prevalent reason in the current study. The second factor associated with challenges in learning English as Secondary Language is the lack of concentration in classes (20\%). In a study conducted among the first year English major students at Qassim University in Saudi (Hamouda, 2013, p. 122), student's assessed their listening skills as "poor". Hamouda also identified what are the usual causes of concentration failure among the students. In her study, the statement "I lose focus of the talk when I have got an expected answer in my mind" is the most common reason disrupting concentration (p. 130). Other common reasons are inability to simultaneously listening to the dialogue while searching for answers in mind and limited English vocabulary (p. 130). The next two challenging factors among the students in the current study are lack of interest and motivation and lack of proficiency and competency on teachers. The graph below illustrates the complete ranking of the part of challenges. Significantly, less than $10 \%$ of the students reported that they face challenges relating to bilingual interference and lack of a constant application. In other words, we can assume that most of the students put their learning in real application outside the school. This statement can further affirm the earlier result where English was used in communicating with the family members. 
Figure 2: Challenges encountered by student in learning English language

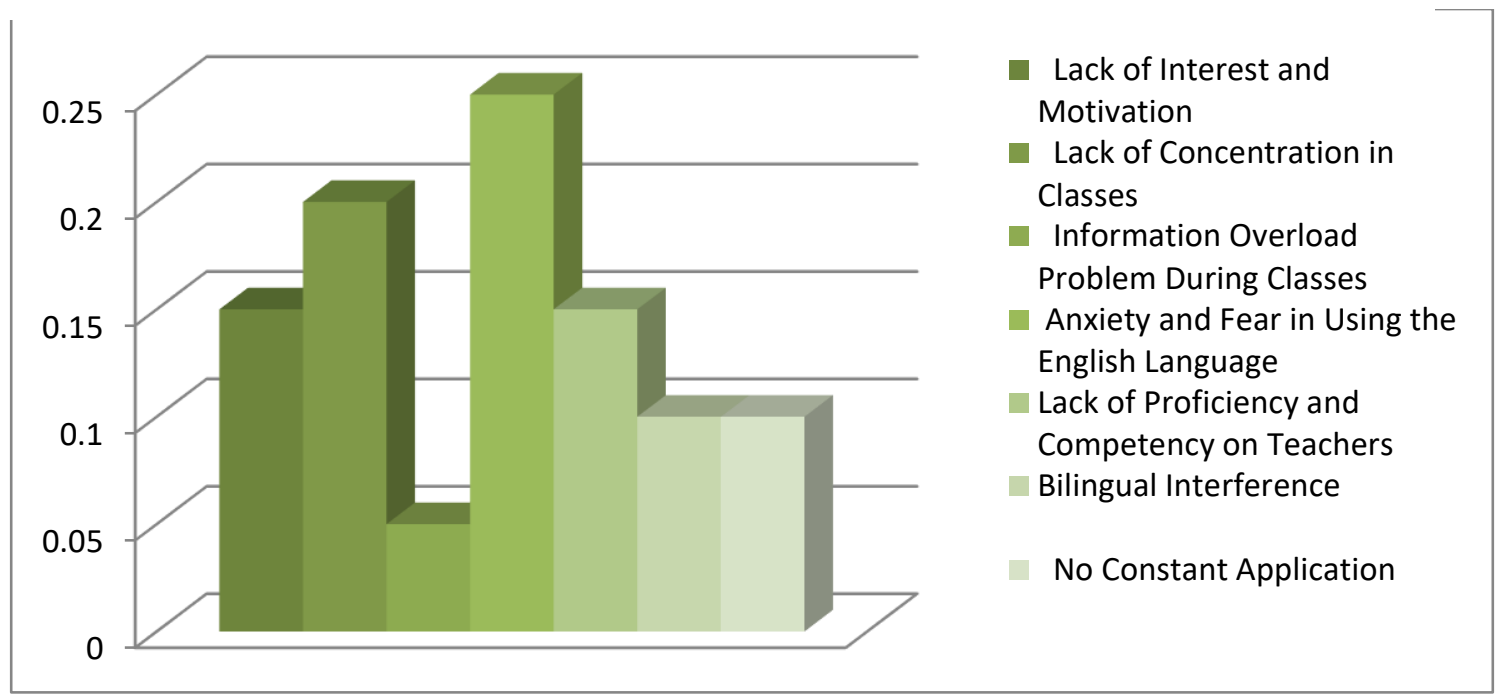

To give a quick measurement of English language communication competency among the students, a qualified evaluator examined the interview sessions through a recorder. He provided remarks on each student interviewed. The following graph shows the complete list of the remarks. In spite of the result that most of the students find it difficult to learn the English language, the majority of them got a "very good" (25\%) and "good" (25\%) remarks from the evaluator. This could imply efficiency of the English language learning strategy currently employed by the students. This is in spite of the fear and anxiety commonly experienced by the students in speaking the language.

Figure 3: Remarks on English fluency

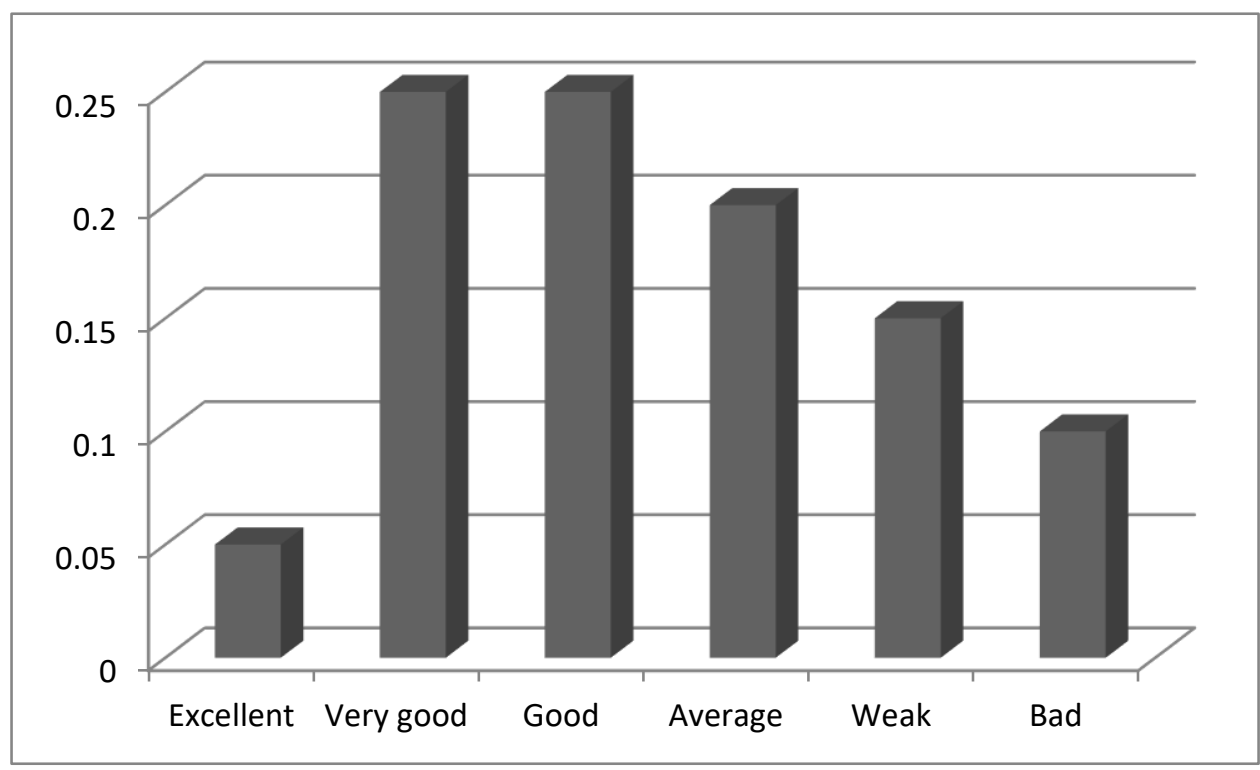

English language is a complex system. Ungureanu (Ungureanu, 2015, p.86) asserted that fluency cannot be obtained by comprehensively focusing on grammar nor by translating words from the mother tongue. Her golden rule is "Speaking is the only requirement to be fluent". That is, by submerging yourself in English- 
speaking environment, learning can progress several times faster. Apparently, from the results obtained, the students are doing the right thing in enhancing their English language skills.

\section{CONCLUSION}

English learning could be challenging for many EL learners. Based on the results, most students admit having a hard time learning English but can actually use the language well. These difficulties may be associated with the complex system of English language per se. Moreover, efficiency in language learning is attributed not just through theoretical inputs from school but most importantly, through constant application outside the school. Like other studies, the most common challenge faced by students is the fear and anxiety associated with English use in public. This challenge primarily roots from the common notion that they might commit a mistake in using the language and will be negatively evaluated by their audience as a result. Confidence is something they can learn as they develop at the later stage of their education. Furthermore, exposing them to various English communication exercises will not just advance their learning but will also boost their self-confidence as time goes by. During the development process, their vocabularies will become more enriched eventually boosting self-confidence. Anxiety and fear in speaking English is a common dilemma among first stage college students. Coupled with the overwhelming transitions during this stage, the students may become emotionally and mentally drained. Thus, teachers and parents should provide proper guidance to the students during this time.

\section{REFERENCES CITED}

Akbari, Zahra, 2015. Current challenges in teaching/learning English for EFL learners: The case of junior high school and high school. Procedia - Social and Behavioral Sciences. 199. pp. 394-401.

Crookall, D. \& Oxford, R. 1991. Dealing with anxiety: Some practical activities for language learners and teacher trainees. In E. K. Horwitz \& D.J. Young. Upper Saddle River, NJ: Prentice Hall, Inc.

Ganschow, L., Sparks, R., \& Javorsky, J. 1998. Foreign Language Learning Difficulties: An Historical Perspective. Journal of Learning Disabilities, 31(3). p. 1-18.

Hamouda, Arafat. 2013. An Investigation of Listening Comprehension Problems Encountered by Saudi Students in the EL Listening Classroom. International Journal of Academic Research in Progressive Education and Development.2(2). pp. 113-155.

Kannan R. 2009.Difficulties in Learning English as Second Language.ESP World, Issue 5(6)

Khajloo, Akram I., 2013.Problems in Teaching and Learning English for Students.International Journal of Engineering Research and Development.7(3). pp. 56-58.

Khan, Intakhab A. 2011. Challenges of Teaching/Learning English and Management. Global Journal of Human Social Science. 11(8)

Mamhot, Alice Mae E., Martin, Maria Hannah V., Masangya, Elaine M. 2013. A Comparative Study on the Language Anxiety of ESL and EFL Learners.Philippine ESL Journal. 10. pp. 200-231.

Muhammad Hamisu A., YauSani., AliyuUmmah I., Hassan Maryam. 2018. Teaching and Learning English Language in Nigerian Schools: Importance and Challenges. Teacher Education and Curriculum Studies.3(1).pp 10-13 
Riyaz, Hafsa and Mullick, Aban P. 2016. Problems in learning English Skill: A Study of Higher Secondary Students in Srinagar, India. International Journal of Interdisciplinary and Multidisciplinary Studies.3(2).pp 59-69.

Schwartz, R., \& Terrill, L. 2000. Adult English Language Learners and Learning Disabilities. Center for Adult Language Acquisition.

Ungureanu, Carmen C. 2015. Why do Some People Say the English Language is Hard to Learn, and Maritime English is Hard to Master. Journal of Shipping and Ocean Engineering. 5. pp. 80-87.

Wold, James B., 2006. Difficulties in Learning English As a Second or Foreign Language. All Regis University Theses. 333. https://epublications.regis.edu/theses/333 